DOI: $\underline{\text { https://doi.org/10.24297/jssr.v15i.8596 }}$

\title{
A Case Study in Curriculum Change on Practicum in A Tesl Programme in Two Malaysian Institutions of Higher Learning
}

\author{
${ }^{1}$ Ramesh Sathappan, ${ }^{2}$ Premaraj Gurusamy \\ ${ }^{1}$ Department of Languages, Temenggong Ibrahim Teacher Education Institute/OUM, Johor, Malaysia, \\ ${ }^{2}$ Kolej Matrikulasi Kejuruteraan Johor/UTM, Malaysia \\ jhnmesh@yahoo.com, premrajg755@gmail.com
}

\begin{abstract}
This study attempts to explain the importance of curriculum change in Higher Learning Institutions. It's objectives were to identify the similarities and differences between two institutions of Higher Learning in terms of curriculum structure, teaching process and teachers' digital skills and also examine whether the curriculum change in their respective training programmes produce better quality teachers in Malaysian schools. A qualitative research incorporating questionnaire, document analysis and interviews was conducted to obtain the results.. The data obtained from the study participants were analyzed qualitatively. The findings of the study reveal that (i) both the Higher Learning Institutions have similarities in prioratizing subject matter, professional standards and practical training (ii) Both of them share the same view that curriculum change has produced better quality teachers. The study concludes by predicting there will be more innovative changes in curriculum designing in the Higher Learning Institutions in future. However, it has recommended more classroom activities for students.
\end{abstract}

Keywords: Curriculum Change, Practicum, Pre-service Teachers

\subsection{INTRODUCTION}

This study attempts to define curriculum change, provide a brief literature review on a detailed description of curriculum change in the programmes of the two selected educational institutions. It goes on to compare and contrast the curriculum change programms conducted in the two educational institutions and concludes with the researcher's recommendations for further research in the curriculum change processes.

Curriculum change incorporates the concepts of innovation, development, renewal and improvement. Change has magnitude and direction. It takes place within a definite time frame. Curriculum change is dictated by the changes in social and technological aspects of a society. Change requires time, energy and resources. However, Curriculum Innovation refers to ideas or practices that are new and different from those that exist in the formal prescribed curriculum. The reason for curriculum change is the desire of the authorities at various levels to deliberately change established practices in order to tackle existing problems or identify new problems and seek ways of dealing with these problems. Curriculum change can also be due to development in technology. Hence, the education system and its curriculum must adapt to this new development.

The strategies to implement the curriculum change must be considered carefully for change to succeed. There are a few of the strategies relevant to this study such as participative problem-solving and the innovation process. In participative problem-solving, the focus is on the users, their needs and how they satisfy their needs. The system identifies and diagnoses its own needs, finds its own solution, tries out and evaluates the solution if it is satisfactory. Here, the emphasis is on local initiative.

In "planned linkage" model, the intermediate agencies such as schools bring together the users of innovation. Coercive strategies work on the basis of power and coercion by those in authority using laws, direction, 
circulars and others. Ministries of education generally use these strategies. The curriculum change agent is involved in the process, the planning and the strategies and also the users of the innovation. The change and innovation generally follow several steps as below:

- Identify a problem, dissatisfaction or need that requires attention.

- Generate possible solutions to the identified problem or need.

- Select a particular solution or innovation that has been identified as the most appropriate.

- Conduct a trial.

- Evaluate the proposed solution.

- Review the evaluation

- If the innovation has been solved the identified problem, implement it on a wide scale.

- Adopt and institutionalise the innovation or search for another solution.

\subsection{BACKGROUND OF THE STUDY}

For this study, two institutions of higher learning were selected for comparison and contrasting. One was a Teacher Education Institute (IPG) and the other one was a Public University in Malaysia. Both of them conduct teacher training Programmes for primary and secondary school pre-service teachers in Malaysia. Department of Languages in the case of IPG, Johor and the Faculty of Education of the public university in Kuala Lumpur, are responsible for the administration and co-ordination of the teacher training programmes. They have similarities as well as differences between them in their approach, especially to practicum i.e. teaching practice.

The researcher has been involved in the supervision of teaching practice for the undergraduates pursuing a Bachelor of Education (TESL) course in the IPG. The teaching practice is carried out throughout the degree course to monitor the progress of the undergraduates in practical teaching. The aim is to expose the students to common school practices and culture. The teaching practice will also provide them with the opportunity to apply their knowledge and skills acquired during lectures in a supportive classroom context. It also seeks to introduce students to the wider role as fully participating members of a school community. Experience gained during this period will enable students to prepare themselves for their teaching career. During teaching practice, the Teacher Education Institute and the public university will assign a supervising lecturer to conduct an observation as the basis for assessment based on the evaluation instrument provided.

\subsection{LITERATURE REVIEW}

The literature on curriculum changes in tertiary education focuses mainly on larger-scale transformations. Much of the academic discussion is concerned with the changes in teaching culture and philosophy that accompany a wholesale move away from traditional (subject-based, knowledge-centered, teaching-focussed) approaches, when institutions turn to alternative (student-based, competence-centered, learning-focussed) approaches that stress the educator's role as a facilitator of learning, rather than a transmitter of knowledge (Bocock, 1994; Huba \& Freed, 2000; Jones, 2000; Merton, Froyd, Penberthy \& Watson 2000). This kind of global transformation will inevitably involve all academic staff in a department, even if introduced incrementally.

Small local changes are usually approved and implemented with a minimum of debate. For example, subjects are sometimes "rested" in a particular year while a staff member is on long service or study leave. This kind of decision is typically made by a Head of Department, or perhaps a small committee of staff administering the particular programme. The formal approval process within the university for such a change is usually 
reasonably streamlined, and one-off amendments to publish guidebooks can sometimes be made just a few weeks before the subject is scheduled to commence.

Changes within a subject may require even less formality. In many institutions, staff are reasonably free to design the content of the subjects they teach so long as broad criteria of tropicality are met. It is often the case that the staff member who has recently moved between institutions or is teaching a subject for the first time may radically change how it is taught, or the tools or languages used in practical work, or the range of issues taught in a particular topic. Indeed, such a change is seeen as an important element in renewal: having the same staff member deliver the same material for too long a time may lead to it becoming stale or irrelevant. The content of subjects may be reviewed or approved by a senior staff member - if such approval is sought. For core topics, however, where change can have implications for subsequent subjects, a broader group of staff is usually involved.

While most research shows that top-down change is not the most desirable method, if change agents find themselves in position of power within the university, research suggests the following general principle of effective curriculum change:

- Change should be conceived as a cycle/journey/process, rather than an outcome, and the vision must therefore be flexible (Holley, 2009; Scott, 2004; Walkington, 2002).

- The change process requires both individual action and collectivism (Walkington, 2002).

- Both top-down and bottom-up strategies are important but care must be taken to integrate them effectively (Blackmore \& Kandiko, 2012; Holley, 2009; Southwell, Gannaway, Orrell, Chalmers, \& Abraham, 2005; Walkington, 2012).

- The change process must involve consultation and connection with the staff as well as the wider university community, particularly students (De La Harpe \& Radloff, 2006; Holley, 2009; Scott, 2004).

- Staff engagement and professional development are key, and this requires allocating time in their work plans (Blackmore \& Kandiko, 2012; Hannan et al., 2006; McKenzie, Alexander, Harper, \& Anderson, 2005).

Johnston (2004) noted the complex nature of the change process that each curriculum differs in educational philosophy or philosophies, students served, programmes offered, consituencies served, institutional mission and other factors. The value of learning from others' experiences in general education reform then, is one of analogy, allegory and adaption rather than adoption of approach and practice. The researcher feels that although the scholars have expressed their merits of curriculum change, the importance of teachers' role cannot be under estimated. So, teacher-related factors have to be considered in curriculum change implementation process. According to Jita (1998), we should not limit our understanding of resources to financial or material resources but should include other resources that influence classroom practices such as human resources, time, sense of mission and commitment as well as textual material. Teachers are considered to be key to the successful implementation of new curricular, as they are the means used to turn innovations into classroom realities (Pinto et al., 2005). Teachers are expected to adopt new ideas and implenent them in their teaching l.e. change in curriculum requires change in teachers' practices (Fullan, 1993). These demands put strain on teachers as it requires them to change their practice and resume the role of "novice" again (Fogelman and McNeil, 2005). Teacher self-efficacy regarding implementing innovation has important implications for teachers who are expected to make changes, because teachers will have different beliefs concerning constraints imposed by the school such as covering the syllabus and teaching for understanding.

\subsection{RESEARCH OBJECTIVES}

The objectives of the study are to: 
1. Identify the similarities and differences between the two institutions of Higher Learning in terms of curriculum structure, teaching process and people

2. Identify if the curriculum change in the teacher training programme has produced better quality teachers in Malaysian schools.

\subsection{RESEARCH QUESTIONS}

The research questions are as follows:

1. What are the similarities and differences between the two institutions of Higher Learning in terms of curriculum structure, teaching process and people?

2. Has the curriculum change in the teacher training programme produced better quality teachers?

\subsection{RESEARCH DESIGN}

Research has been described as a systematic investigation (Burns, 1997) or inquiry wherby data are collected, analyzed and interpreted in some way in an effort to "understand, describe, predict or control an educational or psychological phenomenon or to empower individuals in such contexts" (Mertens, 2005). This research has utilized a qualitative design methodology. According to Draper (2004), qualitative approach can be described as a naturalistic and interpretive approach to understand social phenomena in their social settings to produce 'thick description'. Denzin and Lincoln (1994) point out that qualitative research is "multi-method in focus, involving an interpretive, naturalistic approach to its subject matter".

A qualitative approach was undertaken to analyze data for this study. Research methods used in this study are interviews, questionnaire and document analysis. Questionnaire was used to support the qualitative data. Bogdan and Biklen (1998) define qualitative data analysis as "working with data, organizing it, breaking it into manageable units, synthesizing it, searching for patterns, discovering what is important and what is to be learned, and deciding what you will tell others". Data analysis can be seen as a process through which a researcher searches and arranges the interview themselves, field notes, and other materials gradually (Bogdan \& Biklen, 1998).

Bogdan and Biklen (2003) used the "qualitative research" as the superordinate concept, joining different research approaches with certain common characteristics as well. With the expression "qualitative research", the research is denoted as consisting of the basic empirical material, collected in the research process, which is verbally described or narrated. Furthermore, the collected material is worked on and analyzed in words without numerical operations (Mesec, 1998).

In other authors, (e.g. Denzin \& Lincoln, 2000; Creswell 1998) similar definitions of qualitative research are found. According to Creswell, qualitative research is the research process designed according to a clear methodological tradition of research, whereby researchers build up a complex, holistic framework by analyzing narratives and observations, conducting the research work in the habitat (Creswell, 1998). Fraenkel and Wallen (2006) draw attention to the fact that qualitative researchers mainly focus on the examination of characteristic traits or properties of a certain activity, group, situation, or materials, respectively, but they are not much interested in the frequency of appearance of this activity, group, situation, or material.

Qualitative research is an exploratory approach emphasizing words rather than quantification in gathering and analyzing the data. It is a matter of the inductive, constructivist and interpretative exploratory approach with the following main stresses: to view the world with the eyes of the examinees, to describe and take into account the context, to emphasize the process and not only the final results, to be flexible and develop the concepts and theories as outcomes of the research process (Bryman, 2004). To summarize, for qualitative research, it is characteristic that data are gathered more in a verbal and visual than in a numeric form. When analyzing the 
gathered data, statistical procedures are also not used, but instead predominantly qualitative analysis, the essence of which is searching for codes in the analyzed materials (Bryman, 2004).

The main part of the qualitative analysis of the material is formed by the coding process, i.e. interpreting the analyzed text and attributing the meaning (of key words, notions, codes) to its individual parts (Charmaz, 2006; Bryman, 2004; Flick, 1998), respectively. Qualitative analysis of the material starts with defining the coding units, followed by the appropriate phenomena records according to our judgment and analyzing the characteristics of these phenomena, and ends with the development of the grounded theory (Glaser \& Strauss, 1967). Qualitative research is carried out in line with the principles of the interpretative paradigm, i.e. the focus is on examining the subjective experiences of an individual and on recognizing the importance which the individual attaches to specific events, whereby not even the subjective views of the researcher of the studied situation are neglected (Janesick, 1998).

The aim of qualitative research is to lead to active integrated and detailed cognition of phenomena, preferably in natural and concrete circumstances, for the researcher is interested in the context of the pursued activities. As part of the environment, not only is the researcher able to understand what the person is conveying in the form of a rational message and standardized speech, but also the indirect implications of this speech with a specific syntax, contextual lapses, hidden meanings and speech breaks are perceived. Wishes, expectations, interests, needs and personal opinions of the people included into the research should help the researchers to better comprehend the examined phenomena. In this context, the researcher should be aware of the fact that with their participation - and with the researched situation itself - they are influencing the events they are observing, and the discursive reality, as their research object (Flick, 1998; Denzin \& Lincoln, 2005).

\subsection{Research Method}

Research methods used in this study are interviews, questionnaire and document analysis. The interviews are semi-structured and are used to generate data from IPG and university lecturers. Two lectures from the IPG and another two lectures from the public university are interviewed for this research.

Questionnaires was used to support the qualitative data. It was distributed to 20 students from IPG and another 20 students from the public university. The students are pursuing undergraduate courses in Education (TESL). The issues of suitability and reliability as well as the process of sampling, administration and analysis of the instrument of data collection is discussed in the following section.

\subsection{FINDINGS AND DISCUSSION}

Below are the findings of the study based on the interview and questionnaire with the respondents from the university and the IPG. It also answers the research questions 1 (RQ 1) and research question 2 (RQ 2).

\subsection{RQ 1: What are the similarities and differences between the two institutions}

of Higher Learning in terms of curriculum structure, teaching process

\section{and people?}

\subsubsection{Background of the Institution.}

R1 and R2 explained the purpose of establishment and the curriculum content of IPG. R3 and R4 of the Public University said that the purpose of the establishment was the same i.e. train teachers for schools but their system of curriculum formulation was different as can be seen from the following statements.

R1: "IPG is one of the 27 IPG's established to further enhance the quality of teacher education in Malaysia. IPG plays an important role in providing pre-service and in-service training for primary school teachers in Malaysia. 
It trains teachers at certificate, diploma and degree levels. All the IPG's are controlled by the Headquarter Administration known as IPGM (Institut Pendidikan Guru Malaysia) in Cyberjaya and led by Rektor".

R2: " ... I would like to add some information. To enhance quality teaching, a guideline of Malaysian Quality Framework is used in developing the curriculum used in the IPG's. The TESL curriculum is formulated centrally by the IPG. Curriculum council and accredited by Malaysian Quaifcation Agency (MQA)".

The other two lecturers from the public university gave an account of the purpose and the curriculum of their institution as below:

R3: " Our faculty of education was established in 1991 whose primary role has been training teachers for primary and secondary schools. The Diploma in Education is a postgraduate course offered to those who are selected by the Public Services Commission to pursue a one-year course in teaching".

R4: "Since ours is a public university, we have autonomy in formulating the curriculum for the teacher training programme. However, the curriculum committee is responsible for planning, preparing and co-ordinating the implementation of the approved curriculum".

The researcher's view is that IPG's curriculum is centrally planned whereas the public university has autonomy in formulating its own curriculum. Hence, it is more flexible and changes can be made faster.

\subsubsection{Degree Structure}

R1 and R2 explained the degree structures of TESL and R3 and R4 briefed on their degree structure. There were differences between the two structures. B.Ed (TESL) takes four years in IPG's and BA/B.Sc with Dip. In Education (TESL) of the public university takes five years to complete. The following are the quotes from the four lecturers - R1, R2, R3 and R4.

R1: "It is a four year course spread over eight semesters. The curriculum consists of compulsory, core and elective subjects such as:
1. Compulsory subjects -23 credit hours
2. Core Subjects
- 86 credit hours
3. Electives
$-\underline{24}$ credit hours
Total
133 credit hours

R2: " It is sill a four year course. However, some changes were made in the curriculum structure in 2005. They are:
1. General (subjects)
- 16 credit hours
2. Foundation in Education - 24 credit hours
3. Core Subjects $\quad-48$ credit hours
4. Professional studies $\quad-16$ credit hours
5. Electives $\quad-20$ credit hours
6. Electives (open) $\quad-09$ credit hours 
Total

133 credit hours

The researcher asked R3 and R4 to give a brief account of the teacher training course conducted in their university to compare and contrast between the two institutions.

R3: " Ours is a one-year course after Bachelor's degree in TESL. The Bachelor's degree takes four years to complete. The Diploma in Education is spread over three semesters in one year. The curriculum consists of:

1. Communication skills

2. English Language Proficiency

3. Critical Perspectives in Education

4. ICT for meaningful learning

5. Curriculum and pedagogy for English Language Teaching (ELT)

6. Teaching Practice

R4: "The teaching practice for the trainee teachers is conducted during the second and third semesters. Observation and evaluation are done by the senior English Language Lecturers. It forms $25 \%$ of the whole curriculum. The practical training (practicum) is based on school experience, teaching assistantship, teaching practice 1 and teaching practice $2 "$.

The researcher had further discussion with the four lecturers and found out that there are three similar elements that become the three aspects in these two teacher education institutes which are subject matter, professional element and practical experience in teaching. Both programmes give the trainee teachers the opportunity for in-depth study of some important aspects of education. Curriculum modules are designed to provide teachers with the pedagogical skills to teach specific subjects in schools. However, the total units for the whole programme conducted by IPG is 133 credit hours while the public university requires only 86 credit hours.

\subsubsection{Supervision Process}

According to the supervisors R1 and R2, the process of clinical supervision was used throughout the classroom observations. They were also provided with a form to record the observation. In addition, they also followed closely what is stipulated in the teaching practice handbook. The trainee teachers were advised to refer to the teachers in the school if there was any problem.

Comparatively, R3 and R4 said that the process used for supervision of trainee teachers was based on the criteria for evaluation as stated in the instrument.The instrument is prepared by the curriculum council of the Faculty of Education. The observation consists of three stages i.e. the pre-observation stage, during observation stage and post-observation stage. In his discussion with respondents, the researcher found the following. In the case of IPG, the designers follow the "Planned Linkage" model. Whereas the Faculty of Education of the public university follows the "Innovation Process" model. Both the models have been mentioned earlier in this study.

Innovation model is suitable for the public university because it has the autonomy to experiment and introduce changes fast. Its students population is smaller compared to the total student population of the 27 IPG's throughout the country. On the other hand, "Planned Linkage", model is appropriate. Under this model, the intermediate agencies such as schools bring together the users of innovation. Co-ercive strategies work on the basis of power co-ercion by those in the authority, using laws, direction, circulars and others. Ministries of 
Education generally use these strategies. IPG's curriculum is centrally planned. Kai Zen's theory states that power flows from the top downwards and this is supportive of IPG's curriculum implementation process.

Moreover, during teaching practice, the IPG trainee teachers have to approach the school teachers if they have any problem whereas the undergraduate trainee teachers in the public university are provided with a mentor for assistance and guidance. All of the four supervisors understand their role is to judge whether what has been taught has in fact been carried out properly.

\subsubsection{Supervisors' Responsibilities}

Owing to the presence of the teaching practice assessment form which is the classroom observation instrument, all of the four respondents used the supervisory approach where the supervisors comment on the trainee teachers' performance and make concrete proposals for change. The following are the views from the four respondents:

R1 and R2: "We attend briefing by the teaching practice unit, check the trainee teacher's lesson plan, check all the students' written exercises, complete and submit assessment forms to the Head of Department. We also suggest changes for improvement in teaching performance".

R3 and R4: "Although we agree on the basic functions and responsibilities of the supervising lectures, we would like to propose some changes in their role. As it is, the supervisor is the authority and the trainee teacher is the implementer. So, the assessment is judgmental rather than developmental. The system must be modified to make the relationship between the supervisor and the trainee teacher co-operative and collaborative".

After the discussion, the researcher felt that the IPG supervisors seemed more supportive and caring towards their trainee teachers. R3 and R4 expressed slightly different views. He agreed with R3 and R4 that during teaching practice, the trainee teachers need to be assisted and guided with positive and supportive feedback.

\subsubsection{Management (People)}

Curriculum planning, preparation and co-ordination involve many people at the top level. The next level is the implementation. Curriculum changes must keep pace with the advancement of technology. However, teachers are the implementers at the other end and they need time to upgrade and update themselves for any curriculum change. According to R1, the people involved in the teacher training are the rektor of the Head Quater Adminisration in the IPQM, Cyberjaya, the Director of the Language Department of the IPG, Johor Bahru and the TESL lecturers who are involved in the practicum. R2 added that the curriculum council formulates the curriculum centrally and the Malaysian Qualification accredits the curriculum. TESL lecturers observe trainee teachers during teaching practice. Funds are provided by the Ministry of Education, Malaysia. The management structure of the public university is different from that of the IPG. According to R3, the Faculty of Education of the public university is headed by the dean. The curriculum is designed by the curriculum committee. English Language professors form the teaching staff. They also perform observation duties. R4 added that the University has to raise funds for extra-curricular activities. However, the Faculty of Education is within the jurisdiction of the senate and the vice-chancellor is at the Helm. On comparison, the researcher found that many people are involved in the curriculum management of the IPG whereas in the public university it is less bureaucratic and there is more empowerment to the people involved in planning and implementing the curriculum change.

\subsubsection{Teacher Trainees' Qualities}

All of the four respondents have expressed their views regarding the teacher trainees' qualities - personal and professional.Both R1 and R2 said that the teachers must have the interest and passion for teaching. They must possess communicative and computer skills, leadership qualities and self-confidence. R2 stated that IPG conducts a special course known as Teacher Character Building (TCB) which aims to give an early exposure to 
the ideal characteristics and qualities of teachers which incorporate spiritual and teacher values, high level of endurance knowledgeble and good deeds and the ability to be creative and innovative.

However, R4 expressed caution over the views expressed by the other three respondents. Teacher trainees may possess all the good qualities during the pre- service but what is more important is whether they will maintain and develop their professional skills after training i.e. ICT skills. From the discussion, the researcher concluded that professional development is an on-going process. Jita (1998) too has emphasized the same principle in her research.

\subsection{RQ 2: Has the curriculum change in the teacher training programme produced better quality teachers?}

\subsubsection{Findings from the students of IPG Teacher Trainees'}

\section{1 = strongly disagree $2=$ Disagree $3=$ Neutral $4=$ Agree $5=$ Strongly Agree}

\begin{tabular}{|c|c|c|c|c|c|c|}
\hline \multirow[t]{2}{*}{ No. } & \multirow[t]{2}{*}{ Research Statements } & \multicolumn{5}{|c|}{ Scale (\%) } \\
\hline & & 1 & 2 & 3 & 4 & 5 \\
\hline 1 & $\begin{array}{l}\text { The comprehension topic the teacher } \\
\text { selected for the practicum was within the } \\
\text { scope of the prescribed syllabus. }\end{array}$ & $0 \%$ & $0 \%$ & $10 \%$ & $35 \%$ & $55 \%$ \\
\hline 2 & $\begin{array}{l}\text { The teacher was up-to-date with the } \\
\text { curriculum change in teaching English } \\
\text { Language. }\end{array}$ & $0 \%$ & $12 \%$ & $13 \%$ & $25 \%$ & $50 \%$ \\
\hline 3 & $\begin{array}{l}\text { The teacher was well experienced and } \\
\text { qualified to teach English as a Second } \\
\text { Language. }\end{array}$ & $0 \%$ & $15 \%$ & $0 \%$ & $30 \%$ & $50 \%$ \\
\hline 4 & $\begin{array}{l}\text { The teacher allowed me to participate in the } \\
\text { lessons by motivating me to provide } \\
\text { examples relevant to the topic }\end{array}$ & $50 \%$ & $20 \%$ & $10 \%$ & $5 \%$ & $5 \%$ \\
\hline 5 & $\begin{array}{l}\text { The teacher clarified my doubts whenever I } \\
\text { raised them during the lesson. }\end{array}$ & $50 \%$ & $25 \%$ & $10 \%$ & $15 \%$ & $10 \%$ \\
\hline 6 & $\begin{array}{l}\text { The teacher used audio-visual aids to create } \\
\text { a favourable learning atmosphere in the } \\
\text { classroom. }\end{array}$ & $0 \%$ & $0 \%$ & $10 \%$ & $35 \%$ & $55 \%$ \\
\hline 7 & $\begin{array}{l}\text { The teaching method was different from the } \\
\text { previous one because the approach was } \\
\text { based on instilling Higher Order Thinking } \\
\text { Skills (HOTS). }\end{array}$ & $0 \%$ & $15 \%$ & $0 \%$ & $35 \%$ & $50 \%$ \\
\hline 8 & The Teacher looked confident in delivering & $5 \%$ & $10 \%$ & $5 \%$ & $30 \%$ & $50 \%$ \\
\hline
\end{tabular}




\begin{tabular}{|l|l|l|l|l|l|l|}
\hline & the lesson. & & & & & \\
\hline 9 & $\begin{array}{l}\text { The teacher was co-operative and } \\
\text { supportive in solving students' academic } \\
\text { problems. }\end{array}$ & $0 \%$ & $15 \%$ & $10 \%$ & $40 \%$ & $35 \%$ \\
\hline 10 & $\begin{array}{l}\text { I enjoyed the teacher's teaching style for it } \\
\text { was interesting. }\end{array}$ & $0 \%$ & $10 \%$ & $0 \%$ & $25 \%$ & $65 \%$ \\
\hline
\end{tabular}

\subsubsection{Findings from the students of Public University Teacher Trainees}

\section{1 = strongly disagree $2=$ Disagree $3=$ Neutral $4=$ Agree $5=$ Strongly Agree}

\begin{tabular}{|c|c|c|c|c|c|c|}
\hline \multirow[t]{2}{*}{ No. } & \multirow[t]{2}{*}{ Research Statements } & \multicolumn{5}{|c|}{ Scale (\%) } \\
\hline & & 1 & 2 & 3 & 4 & 5 \\
\hline 1 & $\begin{array}{l}\text { The comprehension topic the teacher } \\
\text { selected for the practicum was within the } \\
\text { scope of the prescribed syllabus. }\end{array}$ & $0 \%$ & $0 \%$ & $10 \%$ & $30 \%$ & $60 \%$ \\
\hline 2 & $\begin{array}{l}\text { The teacher was up-to-date with the } \\
\text { curriculum change in teaching English } \\
\text { Language. }\end{array}$ & $0 \%$ & $10 \%$ & $10 \%$ & $20 \%$ & $60 \%$ \\
\hline 3 & $\begin{array}{l}\text { The teacher was well experienced and } \\
\text { qualified to teach English as a Second } \\
\text { Language. }\end{array}$ & $0 \%$ & $10 \%$ & $20 \%$ & $30 \%$ & $60 \%$ \\
\hline 4 & $\begin{array}{l}\text { The teacher allowed me to participate in the } \\
\text { lessons by motivating me to provide } \\
\text { examples relevant to the topic. }\end{array}$ & $5 \%$ & $10 \%$ & $5 \%$ & $35 \%$ & $45 \%$ \\
\hline 5 & $\begin{array}{l}\text { The teacher clarified my doubts whenever I } \\
\text { raised them during the lesson. }\end{array}$ & $5 \%$ & $15 \%$ & $0 \%$ & $30 \%$ & $50 \%$ \\
\hline 6 & $\begin{array}{l}\text { The teacher used audio-visual aids to create } \\
\text { a favourable learning atmosphere in the } \\
\text { classroom. }\end{array}$ & $0 \%$ & $0 \%$ & $5 \%$ & $35 \%$ & $60 \%$ \\
\hline 7 & $\begin{array}{l}\text { The teaching method was different from the } \\
\text { previous one because the approach was } \\
\text { based on instilling Higher Order Thinking } \\
\text { Skills (HOTS). }\end{array}$ & $0 \%$ & $5 \%$ & $0 \%$ & $35 \%$ & $60 \%$ \\
\hline 8 & $\begin{array}{l}\text { The Teacher looked confident in delivering } \\
\text { the lesson. }\end{array}$ & $10 \%$ & $35 \%$ & $10 \%$ & $20 \%$ & $25 \%$ \\
\hline
\end{tabular}




\begin{tabular}{|l|l|l|l|l|l|l|}
\hline 9 & $\begin{array}{l}\text { The teacher was co-operative and } \\
\text { supportive in solving students' academic } \\
\text { problems. }\end{array}$ & $0 \%$ & $15 \%$ & $5 \%$ & $50 \%$ & $30 \%$ \\
\hline 10 & $\begin{array}{l}\text { I enjoyed the teacher's teaching style for it } \\
\text { was interesting. }\end{array}$ & $0 \%$ & $15 \%$ & $0 \%$ & $45 \%$ & $40 \%$ \\
\hline
\end{tabular}

\subsubsection{Suitability of the Topic}

From the questionnaire results, it can be seen that $55 \%$ of the respondents of the IPG and $60 \%$ of the public university strongly agree that the topic selected was suitable to the level of the students. Another $35 \%$ of the IPG respondents and $30 \%$ of public universities respondents agreed with their view. However, $10 \%$ from each of the Institutes of Higher Learning $(\mathrm{IHL})$ remained neutral. Majority of the respondents from both IHL shared the same opinion that the topic was suitable because it was relevant to the Malaysian culture. Otherwise they would have felt bored.

\subsubsection{Curriculum Change}

$50 \%$ of the IPG respondents and $60 \%$ of the public university respondents strongly agreed that the teacher was up-to-date with the changes in the curriculum. Another 25\% from the IPG and 20\% from the public university agreed with them. However, 13\% (IPG) and 10\% (Public University) of the respondents chose to be neutral. 12\% of IPG respondents and $10 \%$ of the public university respondents disagreed. Majority of the respondents i.e. $50 \%$ from IPG and $60 \%$ from public university strongly agreed that the teacher was familiar with the changes in the curriculum. This could be due to the fact that the trainee teachers are kept informed of the curriculum changes according to the Ministry's circulars.

\subsubsection{Teacher's Language Proficiency}

Majority of the respondents i.e. 55\% from IPG and 60\% from public university strongly agree that the teacher was proficient in Teaching English as a Second Language. Another 30\% from IPG and 30\% from public university agreed with the view but only a minority of the respondents i.e. $15 \%$ from IPG and $10 \%$ from public university disagree.

The findings show that the majority of the respondents had consensus as to the teacher's language proficiency and competence. So, the researcher believes that the teacher training programmes must have been effective in enhancing the language skills of the trainees.

\subsubsection{Student Participation}

$15 \%$ of the IPG respondents strongly agreed and $5 \%$ of them agreed that the students were allowed to participate in the lesson whereas $45 \%$ of the public university respondents strongly agreed and $35 \%$ of them agreed that the students participated in the lesson. 20\% of the IPG respondents and $10 \%$ of the public university respondents agreed. However, $50 \%$ of the IPG respondents and $5 \%$ of the public university respondents strongly disagreed on the issue. Another $10 \%$ from IPG and $5 \%$ from public university remained neutral.

The above findings show that there were sharp differences of opinion between the IPG respondents and public university respondents. Majority of the IPG respondents either strongly or simply disagree while the public university respondents supported the view that the teacher encouraged the students to participate in the lesson. The researcher is of the opinion that students' perception differs and their evaluation is subjective. Perhaps, the IPG respondents have high expectations. 


\subsubsection{Explanation and Clarification of Doubts}

Findings show that only $10 \%$ of the IPG respondents compared to $50 \%$ of the public university respondents strongly agreed that their teacher explained and clarified their doubts during the lesson. Another $15 \%$ from IPG and $30 \%$ from public university expressed their satisfaction. $25 \%$ from the IPG and $15 \%$ from the public university disagreed. However, $50 \%$ of the IPG respondents and $5 \%$ of the public university respondents strongly disagreed with the teacher's explanation and clarification.

Again, IPG respondents and public university respondents did not share the same view regarding the teacher's explanation and clarification. There seems to be some consistency in the assessment standards of the respondents i.e. the IPG group has higher expectations of the teacher's performance compared to that of the public university group. So, they were not satisfied.

\subsubsection{Use of Audio-Visual Aids}

In the case of IPG, a total of $90 \%$ either strongly or simply agreed that the teacher used audio-visual ids to create a learning atmosphere in the classroom compared to $95 \%$ of the public university who either strongly or simply agree with the view. However, $10 \%$ from the IPG and 5\% from the public university remained neutral.

This shows that majority of the respondents from both institutions strongly agree that the audio-visual aids are popularly used in classroom teaching. This is due to the change in the curriculum which emphasizes on the use of technology in classroom teaching. Moreover, it makes the environment more interesting and colourful.

\subsubsection{Teaching Method}

A total of $85 \%$ of the IPG respondents either strongly agreed or agreed that the teaching method incorporated Higher Order Thinking Skills (HOTS) compared to $95 \%$ of the public universities who strongly agreed or agreed with their counterparts' view. However, the minority group i.e. $15 \%$ from the IPG and $5 \%$ from the public university disagreed with the opinion that the teacher applied HOTS in teaching. Curriculum change for schools now includes the HOTS. The objective is to promote thinking skills. Students must become creative and imaginative. The researcher feels that the trainee teachers have successfully learnt to apply what they had learnt during training. This also contributes towards better quality teachers.

\subsubsection{Teacher's Personality}

$50 \%$ of the IPG respondents strongly agreed and 30\% agreed that the teacher looked confident in delivering her lesson. $5 \%$ maintained neutrality, $10 \%$ disagreed and $5 \%$ of them disagreed strongly. Comparatively, $25 \%$ of the public university respondents strongly agreed and $20 \%$ agreed that the teacher looked confident in presenting her lesson, 10\% remained neutral, 35\% disagreed and 10\% disagreed strongly.

When it came to evaluating the teacher's personality for example posture, facial expression and confidence, the respondents from both institutions differed widely. Majority of the IPG respondents i.e. $80 \%$ either strongly agreed or agreed whereas majority of the public university respondents i.e. $45 \%$ either strongly agreed or just agreed that the teacher looked confident in facing the students. Personality is the sum total of the characteristics of an individual. However, evaluation is subjective because individuals tend to use different criteria when judging. It is not possible to produce the best performance always.

\subsubsection{Co-operation and Moral Support}

Findings show that $35 \%$ and $40 \%$ of the IPG respondents strongly agreed and agreed respectively that the teacher was co-operative and supportive in solving their academic problems i.e. 10\% were neutral and the rest (15\%) disagreed. On the other hand, $30 \%$ and $50 \%$ of the public university respondents strongly agreed and 
agreed respectively that the teacher co-operated and gave moral support when they faced problems in studies. Another $5 \%$ of the respondents were neutral and the remaining $15 \%$ disagreed.

On comparison, both the groups recognized their teacher's co-operative and supportive role because their percentage points were almost the same. Only a minority (15\%) disagreed. The researcher believes this kind of a situation is quite normal now because there has been a paradigm shift in the teaching and learning process. For instance, the teacher does not play an authoritarian role but a co-operative and a collaborative role. They have to act as facilitators. This view is supported by Bocock (1994), Huba \& Freed (2000) and Jones (2000) who stresses on educator's role as a facilitator of learning and transmitter of knowledge.

\subsubsection{Student satisfaction and enjoyment}

$65 \%$ of the IPG respondents strongly agreed that they enjoyed the teacher's teaching style and $25 \%$ agreed while $10 \%$ disagreed. Comparatively $40 \%$ of the public university respondents strongly agreed with their counterparts' view and $45 \%$ agreed whereas the remaining $15 \%$ disagreed.

This comparison shows that majority of the respondents from IPG as well as from public university agreed that they were satisfied with and enjoyed their teachers' teaching style. Only a minority disagreed with their perception. The researcher found out that the teacher's ability to arouse the students' interest, motivate and pose challenging questions were the contributory factors. Students' satisfaction and enjoyment is a reflection on the performance of the teacher. However, the training programmes must have played an important role in moulding the trainees to develop positive teaching styles.

\subsection{CONCLUSION AND IMPLICATION}

Change is a fact of life and curriculum change is no exception. Many broad influences shape a curriculum, setting its scope and framing how coherence is achieved. Although, there are similarities across the globe, the curriculum is always shaped by the local context. However, professional and accrediting bodies play an important role in influencing and supporting curriculum change. Johnston (2004) has stated that the complex nature of the change process makes each programme different in educational philosophy and programmes offered.

Findings from the interviews show that there are similarities as well as differences between the two institutions of higher learning namely Institut Pendidikan Guru (IPG) and the public university in terms of structure, process and people. There are three similar elements that become three aspects in this two institutes of higher learning $(\mathrm{IHL})$ which are subject matter, professional aspects and practical teaching.

Both programmes give the trainee teachers the opportunity for in-depth study of some important aspects of education. Curriculum studies modules are designed to provide teachers with the pedagogical skills to teach English as a Second Language in schools. The supervisory duties are also similar. The supervisors from both IHLs understand their role is to judge whether what has been taught has in fact been carried out properly. They use instruments to assess the performance of teacher trainees.

However, differences exist between the two IHLs. In the case of the public university, the Faculty of Education has autonomy in designing the curriculum, incorporating teaching practice whereas IPGs curriculum is centrally planned. In the public university, teacher's training i.e. Diploma in Education is a one-year postgraduate course while in the IPG, it is conducted throughout the four-year course (TESL). The bureaucratic approach of the public university is managing the curriculum change is in line with Halsey's (1992) concept of centralization.

During teaching practice, the IPG trainee teachers have to approach the school teacher if they have any problem but the undergraduate teacher trainees in the public university are provided with a mentor for assistance and guidance. IPG trainee teachers are required to incorporate thinking skills and moral values. They 
are encouraged to use ICT which is useful in the teaching process. In fact, this is a change recently made in the curriculum. The supervisors are more supportive towards their trainee teachers.

However, the scenario in the public university is different. Supervisors exercise more authority over their trainee teachers. For instance, the supervisor directs and the trainee teacher implements. The focus in public university is on communication skills. The trainee teachers must acquire hands-on learning via the transfer of theoritical knowledge to real life situations. Language enhancement and academic-diacource skills provide trainee teachers with oral and written skills necessary for effective communication as teachers in both classroom teaching and in their professional interaction with others.

Results from the questionnaire survey show that the two IHLs have more areas of agreement that disagreement as to whether the curriculum change has produced better quality teachers. Both of them agreed that the trainee teachers possess the qualities of passion for teaching, ability to communicate well, creative spirit, confidence and leadership qualities. However, they disagreed on the following areas: students' participation in classroom activities, clarification of doubts and the teachers' teaching style. The findings prove that the curriculum change introduced in the two IHLs have successfully produced better quality teachers. This study also implies that there will be changes in curriculum in both the institutions of higher learning. As the political, economic and social situations change, curriculum change will become a necessity. Change is an ongoing process so it is inevitable.

\subsection{RECOMMENDATION}

However, it is recommended that supervisors respect trainee teachers and provide a conducive and effective atmosphere in teaching and learning. Supervisors must provide a supportive feedback to the trainee teachers throughout their study. Supervisors and trainee teachers should work cooperatively and collaboratively to learn from each other. There should be a re-orientation in future in the teacher training programmes. Teachers should not merely impart knowledge but go beyond that and explore the hidden talents of the students.

\section{REFERENCES}

1. Blackmore, P., \& Kandiko, C.B. (2012). Processes and resources. In P. Blackmore \& C.B. Kandiko (Eds.), Strategic curriculum change: Global trends in universities. Abingdon, UK: Routledge.

2. Bocock, J. (1994). Curriculum change and professional identity: The role of the university lecturer, in J. Bocock \& D. Watson, eds, Managing the University Curriculum: Making Common Cause, Open University Press, 116-126.

3. Bogdan, R. C. \& Biklen, K. S. (2003). Qualitative Research for Education. An

4. Introduction to Theory and Methods. Boston: Allyn and Bacon.

5. Bryman, A. (2004). Social Research Methods. New York: Oxford University Press.

6. Burns, R. B. (1997). Introduction to research methods. Addison Wesley Longman.

7. Bush, T. (2007). Educational leadership and management: Theory, policy and practice. South African Journal of Education, 27(3), 391-406.

8. Charmaz, K. (2006). Constructing Grounded Theory. London: Sage Publications.

9. Cohen, L. Manion, L. \& Morrison K. (2000). Research Methods in Education. London: Routledge Falmer.

10. Creswell, J. W. (1998). Qualitative inquiry and Research Design. Thousand Oaks: Sage. 
11. De la Harpe, B., \& Radloff, A. (2006). Lessons learned from three projects to design learning environments that support 'generic' skill development. Journal of Learning Design, 21, 655-686.

12. Denzin, N. K., Lincoln Y. S. (2000): Handbook of Qualitative Research. London: Sage Publications.

13. Denzin, N. K. (2005). The Research Act. New York: mcgraw- Hill Book Company.

14. Draper (2004). Focus-group interview and data analysis. Proceedings of the nutrition society, 63(04), 655-660.

15. Fraenkel, J. R. \& Wallen, N. E. (2006). How to design and evaluate research in Education. New York: mcgrawHill.

16. Flick, U. (1998). An Introduction to Qualitative Research. Sage Publication.

17. Fogleman, J., \& mcneill, K. L. (2005). Comparing teachers' adaptations of an inquiry-oriented chemistry unit. In annual meeting of the American Educational Research Association, Montreal, Canada.

18. Froyd, J., Penberthy, D., \& Watson, K. (2000). Good educational experiments are not necessarily good change processes. In Proceedings of the Thirteenth ASEE/IEEE Frontiers in Education Conference, 2, Kansas City, MO, pp. F1G1-6.

19. Fullan, M. G. (1993). Why teachers must become change agents. Educational leadership, 50, 12-12.

20. Glaser, B. G. \& Strauss, A. L. (1967). The Discovery of Grounded Theory:

21. Strategies for Qualitative Research. Chicago: Aldine.

22. Hannan, A., English, S., \& Silver, H. (2006). Why innovate? Some preliminary findings from a research project on innovations in teaching and learning in higher educations. Studies in Higher Education, 24, 279-289.

23. Holley, K.A. (2009). Interdisciplinary strategies as transformative change in higher education. Innovative Higher Education, 34, 331-334.

24. Huba, M.E. \& Freed, J.E. (2000). Learner-centered Assessment of College Campuses: Shifting the focus from Teaching to Learning. Allyn \& Bacon.

25. Janesick, V. J. (1994). The dance of qualitative research design: Metaphor, methodolatry, and meaning.

26. Mertens, D. R. (2005). Rate and extent of digestion. Quantitative aspects of ruminant digestion and metabolism, 2, 13-47.

27. Jita, L. (1998). Resources for transforming science teaching in schools in Africa. In Education Africa Forum , vol. 2, pp. 52-55.

28. Johnson, R. B.(2004). Mixed methods research: A research paradigm whose time has come. Educational researcher, 33(7), 14-26.

29. Jones, E.A. (2002). Transforming the curriculum: Preparing students for a changing world.. ASHE-ERIC Higher Education Report, 29(3).

30. Kajornboon, A. B. (2004) Creating Useful Knowledge: A Case Study of Policy Development in E-learning at Chulalongkorn University Language Institute. Dissertation. University of Melbourne: Australia. 
31. Mckenzie, J. Alexander, S., Harper, C., \& Anderson, S. (2005). Dissemination, adoption \& adaptation of project innovations in higher education. Sydney, Australia: Carrick Institute for Learning and Teaching in Higher Education.

32. Merton, P., Clarke, C., Richardson, J., \& Froyd, J. (2001). Engineering curricular change across the foundation coalation: Potential lessons from qualitative research. In Proceedings of Thirty-first ASEE/IEEE Frontiers in Education Conference, 3, Reno, NV. Pp. F4B15-20.

33. Mesec, B. (1998). Introduction to Qualitative Research in Social field. Ljubljana: Pearson Education.

34. Methodolatry, and Meaning. In: Denzin, N. K. And Lincoln, Y. S., Strategies of Qualitative Inquiry.

35. Patton, M. Q. (2000). Qualitative Research and Evaluation Method. London: SAGE Publications.

36. Pinto, R. (2005). Introducing curriculum innovations in science: Identifying teachers' transformations and the design of related teacher education. Science Education, 89(1), 1-12.

37. Scott, G. (2004). Change matters: Making a difference in higher education. In Rob Carmichael (Ed.), Proceedings of the Australian universities Quality Forumn 2004: Quality in a Time of Change. Melbourne, Australia: Australian Universities Quality Agency, 35-51.

38. Southwell, D., Gannaway, D., Orrell, J., Chalmers, D., \& Abraham, C. (2005). Strategies for effective dissemination of project outcomes. Sydney, Australia: Carrick Institute for Learning and Teaching in Higher Education.

39. Taylor, S. J., \& Bogdan, R. (1998). In-depth interviewing. Introduction to qualitative research methods, 3, 87-116.

40. Walkington, J. (2002). A process for curriculum change in engineering education. European Journal of Engineering Education, 27, 133-148. 